Confronta tipicidade e atipicidade, atribuindo a esta uma significação galgada no que chamou de "binômio funidamental" formado entre a idéia de autonomia privada "re-significada" e de tipo contratual. Utiliza base empírica para classificar as manifestaçốes da atipicidade. Propõe uma interpretação contratual fundada no referido "binômio". Utuliza, assim, o método tipológico, tomando os tipos como facilitadores do processo hermenêutico, na medida do que chama de "coeficiente elástico do tipo".

A banca examinadora foi composta pelos Professores: Cesar Yiterbo Matos Santolim, da Universidade Federal do Rio Grande do Sul e Doutor em Direito pela mesma, Gerson Luiz Carlos Branco, da Universidade Luterana do Brasil e Doutor em Direito pela Universidade Federal do Rio Grande do Sul e Maria Alice Costa Hofmeister, da Pontificia Universidade Católica do Rio Grande do Sul e Doutora em Direito pela Universidade Federal de Santa Catarina. A referida defesa foi presidida pela Professora Doutora Judith Hofmeister Martins-Costa.

\title{
o Silêncio na Formação do Contrato: Elementos Qualificadores de sua Valoração Declarativa
}

Por Priscila David Sansone Tutikian

Data da defesa da dissertação: 1 1/06/2007

Orientadora: Judith Hofmeister Martins-Costa

A dissertação se destina a investigar, de modo especial, se a admissão do silêncio como anuência pode ser verificada no momento de criação do vínculo contratual, de formação dos contratos. Ainda, objetiva-se definir quais elementos são qualificadores dessa realidade. Dentre outras circunstâncias, a dissertação avalia se o silenciar de um dos participantes da fase de formação do contrato tem a potencialidade de despertar no destinatário da declaração uma confiança legítima de que o contrato se concluíra. Se caracterizada essa confiança, surgirá, de forma ainda mais evidente, a demanda de se examinar se o silêncio poderá ser - ou se necessariamente será - tido como aceitação.

Analisando os elementos que qualificarão o silêncio como anuência no domínio jurídico da formação contratual, são tomados como objeto de análise tanto os elementos previstos no artigo 111 do Código Civil, avaliando-se as conjunturas positivas e negativas da valoração do silêncio, quanto, em caráter exemplificativo, outros elementos do ordenamento que influenciam a realidade na qual o silêncio se insere. 
A eleição da fase de formação dos contratos justifica-se na medida em que é nesse cenário que o silêncio causa maior polêmica. Enfrentase, assim, tema pouco explorado pela doutrina nacional, sendo, todavia, útil e necessário o estabelecimento de sua compreensão dogmática no Direito brasileiro.

A banca examinadora foi composta pelos Professores Doutores: Adalberto de Souza Pasqualotto, da Pontificia Universidade Católica do Rio Grande do Sul e Doutor em Direito pela Universidade Federal do Rio Grande do Sul Carlos Klein Zanini, da Universidade Federal do Rio Grande do Sul e Doutor em Direito pela Universidade de São Paulo; Renan Lotufo, da Pontificia Universidade Católica de Săo Paulo e Doutor em Direito pela mesma instituição. A referida defesa foi presidida pela Professora Judith Martins-Costa.

Interpretação do Contrato e Objetivação de Interesses

Por Marcelo Vicenzi

Data da defesa da dissertação: 17/09/2007

Orientadora: Véra Maria Jacob de Fradera

A dissertação examina a interpretação do contrato diante do quadro da objetivação das relações jurídicas negociais. Expóe os fundamentos e os aspectos problemáticos da teoria interpretativa, com informações de direito comparado. Evidencia que há de se contar não apenas com as declarações de vontade das partes, mas também com as circunstâncias objetivas que as rodeiam. Analisa os critérios de interpretação do contrato recepcionados em nosso sistema normativo, a fim de verificar se e em que medida as disposições que disciplinam o procedimento hermenêutico consagram relevância aos interesses dos contratantes.

A banca examinadora foi composta pelos Professores: Carlos Klein Zanini, da Universidade Federal do Rio Grande do Sul e Doutor em Direito pela Universidade de São Paulo; Paolo Carbone, da Universidade de Sassari/ Itália e Doutor em Direito Comparado pela Universidade de Palermo/Itália; e Luis Renato Ferreira da Silva, da Pontificia Universidade Católica do Rio Grande do Sul e Doutor em Direito pela Universidade de São Paulo. A referida defesa foi presidida pela Professora Doutora Véra Maria Jacob de Fradera. 